\title{
Can Surfactant Be Used in Treatment of Rhinitis Medicamentosa? An Experimental Animal Study
}

\author{
(1) Melis Demirağ Evman, ${ }^{1}$ [1] Hakan Avcl, ${ }^{1}$ (]) Kayhan Başak, ${ }^{2}$ (1) Murat Sarı ${ }^{3}$
}

'Department of Otorhinolaryngology, University of Health Sciences, Kartal Dr. Lütfi Kırdar Training and Research Hospital, İstanbul, Turkey 2Department of Pathology, University of Health Sciences, Karta Dr. Lütfi Kırdar Training and Research Hospital, İstanbul, Turkey 32Department of Otorhinolaryngology, Marmara University Pendik

Training and Research Hospital, İstanbul, Turkey

Submitted: 14.05.2020 Accepted: 08.07.2020

Correspondence: Melis Demirağ Evman, 'SBÜ Kartal Dr. Lütfi Kırdar Eğitim ve Araştırma Hastanesi, Kulak Burun Boğaz Anabilim Dalı İstanbul, Turkey

E-mail: melisdemirag@hotmail.com

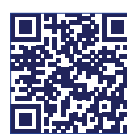

Keywords: Mometasone furoate; nasal mucosa; rhinitis medicamentosa; surfactant.

\section{(1) (1)}

This workis licensed under a Creative Commons This workis icensed under a Creative Commons

\begin{abstract}
Objective: Rhinitis medicamentosa (RM) is a nonallergic form of rhinitis, mostly associated with prolonged, excessive, and improper use of topical decongestants. The only effective treatment for this is nasal steroids. This study aimed to reverse the mucosal changes in RM by the use of surfactant. Different molecules were applied to each group to compare surfactant's effectiveness.
\end{abstract}

Methods: Thirty rats were divided into five groups. All groups were treated with topical oxymetazoline $0.05 \%$ for 30 days. Loss of cilia, congestion, edema, goblet cell growth, and increase in mucous glands, squamous metaplasia, and chronic inflammatory cell infiltration were set as the main parameters. Rats in group 5 were sacrificed; all proved the presence of mucosal changes in compliance with RM. All groups were continued to be treated with oxymetazoline even during the histopathological examination period of 15 days. Treatment modalities of each group for 15 days were as follows: saline wash $(0.09 \% \mathrm{NaCl})$ in group $\mathrm{I}$, mometasone furoate monohydrate $50 \mu \mathrm{g} 0.05 \%$ in group 2 , surfactant wash solution I drop/ $100 \mathrm{cc}$ in group 3, and intranasal surfactant solution with mometasone furoate monohydrate $0.05 \%$ in group 4 . All rats were decapitated and sent for histopathological evaluation at the end of day 60 .

Results: A significant regression in the nasal mucosal congestion was found in groups treated with saline and mometasone furoate $(p=0.005)$. No significant difference was found between groups when evaluating for regression of loss of cilia but unpredictably was seen in saline group by $83 \%$. Surfactant/mometasone furoate combination therapy was found to be significantly ineffective for treatment of edema $(p=0.013)$. No statistical difference was found between the groups in terms of chronic inflammatory cell infiltration $(p=0.115)$. Squamous metaplasia was observed in all treatment groups, and there was no statistically significant difference between the groups $(p=0.076)$

Conclusion: Surfactant or its combination with nasal steroid is not significantly effective in the treatment of RM.

\section{INTRODUCTION}

Rhinitis medicamentosa (RM) is one of the nonallergic forms of rhinitis; it is also known as chemical or rebound rhinitis. The most common reason for its occurrence is the overuse of topical decongestants, especially oxymetazoline and xylometazoline. Use of drugs such as phosphodiesterase inhibitors (e.g., sildenafil), antipsychotics, oral contraceptives, antihypertensive drugs, or analgesics (e.g., salicylates, nonsteroid anti-inflammatory drugs, etc.) may also be the reason for the occurrence of RM. ${ }^{\left[{ }^{[}\right]}$

The main complaint in RM is nasal congestion because of edema and vasodilation in the nasal mucosa. ${ }^{[1]}$ The persistent nasal congestion, usually without rhinorrhea or postnasal discharge, forces patients to increase the use of drugs, which ends up in dependence on topical nasal decongestants. The incidence of RM is about $1 \%-7 \%$, and it is observed more frequently in young and middle-age adults, without any gender dominance. ${ }^{[2-4]}$

RM leads to various histopathological changes in the nasal mucosa such as congestion, edema, cilia loss, chronic inflammation, squamous metaplasia, increase in number of goblet cell, and increase in mucous glands. ${ }^{[1,2]}$ The changes, especially the ones on secretory elements, in the mucosa contribute to clinical symptoms seen in RM. ${ }^{[5]}$ Because of the prolonged use ( 10 days to 8 weeks) of nasal decongestants, parasympathetic response was downregulated and the sympathetic system response was 
upregulated causing a decrease in the release of the nasal surfactant. ${ }^{[6-11]}$

Although the etiology of RM is not known exactly, some hypotheses related to its formation are present. Vasoconstrictors induce vasoconstriction via alpha receptors of the nasal mucosa. When the effect disappears, rebound vasodilation occurs causing edema of the mucosa. ${ }^{[12]}$ Adrenergic receptors become refractory to nasal decongestants because of the overuse, causing patients to use nasal decongestants more frequently at higher doses. ${ }^{[13-15]}$

Surfactant is composed of lipids and proteins. It is mainly secreted from type 2 alveolar cells. It is also secreted from the proximal airway epithelia. It has a role in immune system regulation, inflammatory response, phagocytosis, and clearance of apoptotic cells, and it also plays an antimicrobial role in sinonasal epithelium. ${ }^{[16]}$

The first step in the treatment of RM is stopping the use of topical decongestants. Topical nasal steroids are the most effective and commonly used drugs in RM treatment. Systemic steroids may also be used, but there is no evidence-based data. ${ }^{[17]}$

Since there are very few studies on RM, knowledge about the pathophysiology is based on existing case reports and histological studies in literature. Hereby, in the current study we aimed to investigate the efficacy of surfactants in reversing histopathologic changes attributable to RM.

\section{MATERIALS AND METHODS}

The Marmara University Animal Experiments Local Ethics Committee approved the animal use protocol for this study (38.20 I5.mar).

Thirty healthy Wistar albino rats, both male and female, weighting 200-240 g were divided into 5 groups, each group consisting of 6 animals (Table I). Animals were observed in the laboratory for a week to make sure they do not have any pathology. They were kept in steel cages and fed with standard laboratory food. No food or fluid restrictions were made.

Drugs were administered intranasally by micropipette (Fig. I). Oxymetazoline 0.05\% (Iliadin, Merck, Germany) was administered $50 \mu \mathrm{L}$ on each nasal passage 3 times a day for 30 days to all groups. Following the 30 -day period, all

Table I. Experimental groups

$\begin{array}{ll}\text { Group I } & \begin{array}{l}\text { Oxymetazoline for } 45 \text { days, followed by saline for } \\ \text { I5 days } \\ \text { Oxymetazoline for } 45 \text { days, followed by } \\ \text { mometasone furoate for I5 days }\end{array} \\ \text { Group } 3 & \begin{array}{l}\text { Oxymetazoline for } 45 \text { days, followed by surfactant } \\ \text { for } 15 \text { days }\end{array} \\ \text { Group } 4 & \begin{array}{l}\text { Oxymetazoline for } 45 \text { days, followed by surfactant/ } \\ \text { mometasone furoate combination for } 15 \text { days }\end{array} \\ \text { Group } 5 & \begin{array}{l}\text { Oxymetazoline for } 30 \text { days } \\ \hline\end{array}\end{array}$

the animals in the control group (group 5) were sacrificed to detect histopathological changes in the nasal mucosa in compliance with RM. Rest of the groups were continued to be treated with oxymetazoline during histopathological examination period ( 15 days). Rats in group I were given intranasal saline $(0.09 \% \mathrm{NaCl})$, group 2 rats were given intranasal mometasone furoate monohydrate $0.05 \%$ (Mometix AQ, Drogsan, Turkey) once a day $50 \mu g$, group 3 rats were treated with surfactant wash solution (Abfen Sinus Rinse Kit-S, Abfen Farma, Turkey) I drop/100 cc, group 4 rats were given intranasal surfactant solution combined with mometasone furoate monohydrate $0.05 \%$ once a day $50 \mu \mathrm{g}$ at each nasal passage for I 5 days (Table I).

Decapitation of the rats was performed at the end of 60 days with a combination anesthesia and intraperitoneal $80 \mathrm{mg} / \mathrm{kg}$ of ketamine hydrochloride (Ketalar, Eczacıbaşı, Turkey) and $8 \mathrm{mg} / \mathrm{kg}$ xylazine (Rompun, Bayer, Turkey). The skin was removed from heads and was placed in $10 \%$ formaldehyde solution and was randomly numbered for histopathologist to evaluate the nasal mucosa without bias (Fig. 2).

Formaldehyde solution ( $10 \%$ buffered) was used for fixation of the samples; then, nitric acid (10\% buffered) was used for $\mathbf{4 8}$ hours for decalcification. After decalcification decalcifying solution was washed under running water and tissues were put in formaldehyde solution for 2 days for fixation. Later, dehydration, opacification, and paraffinization were done, respectively.

Specimens were sliced with 3-5 $\mu \mathrm{m}$ thickness by Leica

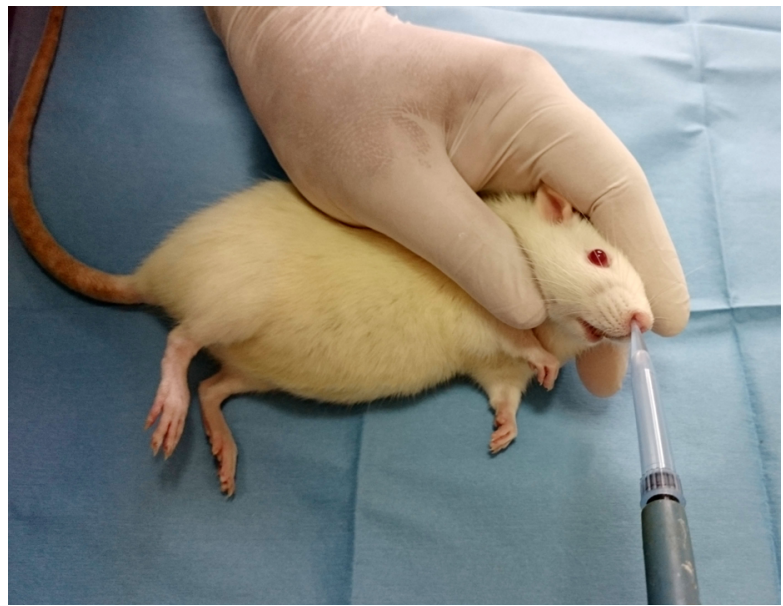

Figure 1. Intranasal drug administration to rat by micropipette.

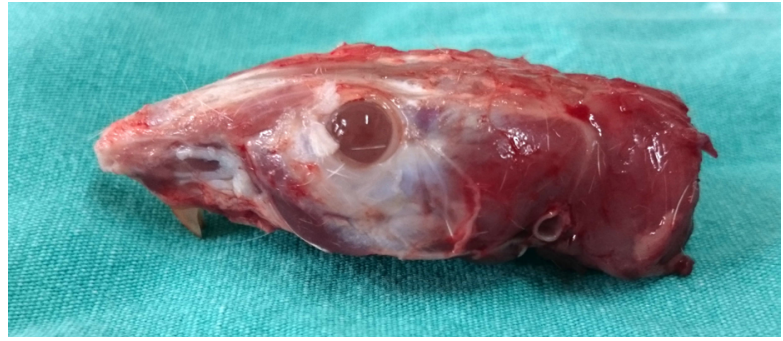

Figure 2. Specimen after decapitation. 
Table 2. Evaluation of groups according to histopathological findings

\begin{tabular}{|c|c|c|c|c|c|}
\hline & Saline & Surfactant & Nasal steroid & Surfactant+Steroid & $\mathbf{p}$ \\
\hline & n (\%) & n (\%) & n (\%) & n (\%) & \\
\hline Loss of cilia & I (I6.7) & $5(83.3)$ & $4(66.7)$ & $5(83.3)$ & 0.071 \\
\hline Congestion & $2(33.3)$ & $6(100)$ & $2(33.3)$ & $6(100)$ & $0.005^{*}$ \\
\hline Edema & $2(33.3)$ & I (I6.7) & I (I6.7) & $6(100)$ & $0.013^{*}$ \\
\hline Goblet cell increase & I (I6.7) & I (I6.7) & $4(66.7)$ & $3(50)$ & 0.277 \\
\hline Squamous metaplasia & $0(0)$ & $4(66.7)$ & $4(66.7)$ & $3(50)$ & 0.076 \\
\hline Chronic inflammatory cell infiltration & $2(33.3)$ & $6(100)$ & $5(83.3)$ & $4(66.7)$ & 0.115 \\
\hline Increase in mucous gland number & I (I6.7) & $2(33.3)$ & $2(33.3)$ & $3(50)$ & 0.931 \\
\hline
\end{tabular}

Fisher Freeman Halton Test ${ }^{*} p<0.05$.

RM2125RT microtome. Prepared sections were stained by hematoxylin and eosin, and they were evaluated by Olympus BX53 light microscope. Loss of cilia, congestion, edema, goblet cell growth, squamous metaplasia, chronic inflammatory cell infiltration, and surface epithelial loss were evaluated. Scoring was as follows: 0-no change (none) or normal, I-any change (mild/moderate/severe).

The numerical data of the findings were analyzed by "IBM SPSS Statistics V.22 (IBM Inc., NY, US)” statistical program. The distribution of data was checked by KolmogorovSmirnov test. Kruskal-Wallis and Mann-Whitney $U$ tests were used for intergroup comparison. Qualitative data were analyzed with Fisher-Freeman-Halton test. p-values of $<0.05$ were accepted statistically significant.

\section{RESULTS}

The histopathological parameters evaluated in this study were loss of cilia, congestion, edema, goblet cell growth and increase in mucous glands, squamous metaplasia, and chronic inflammatory cell infiltration.

The results are summarized in Table 2 .

\section{Loss of cilia}

There was no statistical significance between groups; unpredictably, there was regression in loss of cilia by $83 \%$ in the saline group $(p=0.07 \mathrm{I})$ (Fig. 3a).

\section{Congestion}

In groups treated with saline (group I) and nasal steroid, there was significant regression in the nasal mucosal con- gestion $(p=0.005)$ (Fig. 3b).

\section{Edema}

Surfactant and nasal steroid combination treatment was of no use in terms of regression of edema; however, significant improvement was observed in other three groups $(p=0.013)$.

Goblet cell growth and increase in mucous glands No statistical significance was found between groups $(p=0.277)$ (Fig. 3c).

\section{Squamous metaplasia}

There was full recovery in the group treated with saline, although no significant difference between the groups was found $(p=0.076)$.

\section{Chronic inflammatory cell infiltration}

Despite not reaching the significance level, saline was the most effective treatment of choice in terms of regression of chronic inflammatory cells among other examined molecules $(p=0.115)$ (Fig. 3d).

\section{DISCUSSION}

RM is also called as chemical rhinitis or rebound rhinitis. It is caused by many systemic drugs but occurs mainly because of the prolonged and improper use of nasal decongestants. ${ }^{[1]}$ They cause histopathologic changes in the nasal mucosa. ${ }^{[2]}$ The main complaint of RM is nasal congestion because of edema of the nasal mucosa. Cessation of nasal
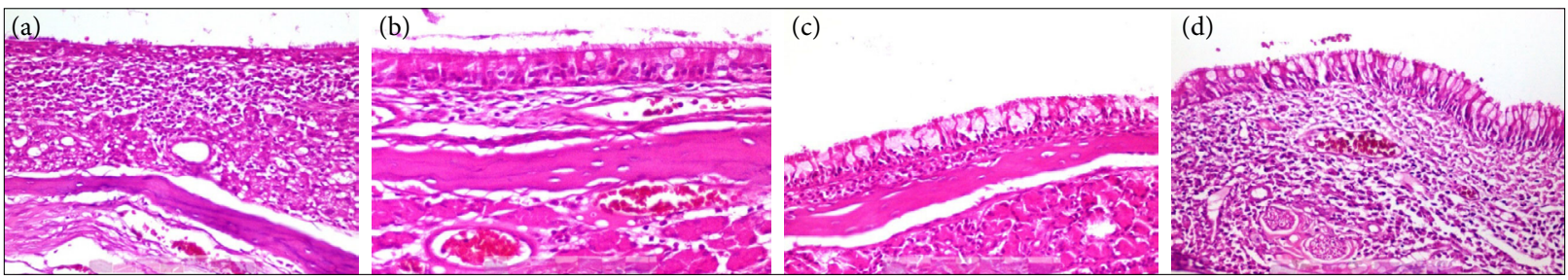

Figure 3. (a) Diffuse cilia loss (H\&E 200). (b) Congestion in the mucosa with enlarged vessels filled with erythrocytes (H\&E 200). (c) Goblet cell growth (H\&E 200). (d) Chronic inflammatory cell infiltration (H\&E 200). 
decongestants is the first-line treatment. Currently, nasal steroids are the only known and effective treatment of RM. ${ }^{[17]}$ Systemic steroids or antihistaminic drugs may be used to relive symptoms. ${ }^{[1]}$

In the study by Zhu et al. ${ }^{[8]}$ it was histopathologically shown that surfactant significantly improves ciliary morphology, reverses the edema, and decreases the number of goblet cells; therefore, it could have protective and hyposecretory effects on mucociliary system in the eustachian tube mucosa. Our study reported that use of surfactant or its combination with nasal steroid was ineffective in terms of mucosal recovery when compared to saline or steroid.

The use of saline solution or solutions at various sodium concentrations was recommended in some studies to keep the nasal mucosa moisturized. ${ }^{[19]}$ Hypertonic saline solutions have been considered to have weak antiedema effect. ${ }^{[20,21]}$ Although our study did not achieve the significance level, it stated that saline was the only effective molecule for amelioration of ciliary cell loss and chronic cell infiltration or squamous metaplasia.

Studies had shown that nasal corticosteroids were effective on nasal edema, inflammation, and congestion regression. ${ }^{[22,23]}$ Unlike these studies, our study could not demonstrate any significant recovery in aforementioned parameters within nasal steroid nor surfactant and nasal steroid combination therapy groups.

RM is a condition that deteriorates the quality of life. There is no standardized approach or established guideline for the treatment of RM in the current literature other than avoidance of the topical decongestants. ${ }^{[24,25]}$ Local steroids are the most common drugs used in daily practice. In our study we administered surfactant and surfactant and nasal steroid combination to rats with histopathologically confirmed RM. Our study revealed that molecules applied were not able to create the expected regeneration on the nasal mucosa. In clinical practice, nasal steroids are the most common drug prescribed for patients with nasal congestion. Nasal wash solutions are also recommended for additional relief. Some nasal wash solutions contain surfactant, but combination of surfactant and nasal steroid was found to be ineffective in regression of edema and congestion of the nasal mucosa in our study.

\section{CONCLUSION}

The present study concluded that surfactant or its combination with nasal steroid is not as effective as sole saline administration for the regression of histopathological changes in RM.

\section{Ethics Committee Approval}

Approved by the Marmara University Animal Experiments Local Ethics Committee (38.2015.mar).

Peer-review

Internally peer-reviewed.
Authorship Contributions

Concept: M.D.E., M.S.; Design: M.S., K.B.; Supervision: M.D.E., H.A.; Materials: M.D.E., H.A.; Data: M.S., K.B.; Analysis: M.D.E., H.A., M.S.; Literature search: M.D.E., H.A.; Writing: M.D.E., M.S.; Critical revision: K.B., M.S.

Conflict of Interest

None declared.

\section{REFERENCES}

1. Doshi J. Rhinitis medicamentosa: what an otolaryngologist needs to know. Eur Arch Otorhinoloryngol 2009;266:623-5.

2. Ramey JT, Bailen E, Lockey RF. Rhinitis Medicamentosa. J Investig Allergol Clin Immunol 2006;16:148-55.

3. Dokuyucu R, Cevik C, Ozler GS, Ozgur T, Arli C, Sefil F, et al. Determination of oxidative stres and effect of erdostine on rhinitis medicamentosa in a rat model. European Journal of Pharmacology 2014;742:153-7.

4. Graf P. Rhinitis medicamentosa: a review of causes and treatment. Treat Respir Med 2005;4:21-9.

5. Lin CY, Cheng PH, Fang SY. Mucosal changes in rhinitis medicamentosa. Ann Otol Rhinol Laryngol. Ann Otol Rhinol Laryngol 2004;113:147-51.

6. Ruskin SL. Differential diagnosis and therapy of atrophic rhintis and ozaena. Arch Otolaryngol 1932;15:222-57.

7. Elwany S. Abdel-Salaam S. Treatment of rhinitis medicamentosa with fluticasone proprionate an experimental study. Eur Arch Otorhinolaryngol 2001;258:116-9.

8. Mortuaire G, de Gabory L, François M, Massé G, Bloch F, Brion N, et al. Rebound congestion and rhinitis medicamentosa: Nasal decongestants in clinical practice. Critical review of the literature by a medical panel. Eur Ann Otorhinolaryngol Head Neck Dis 2013;130:137-44.

9. Watanabe H, Foo TH, Djazaeri B, Duncombe P, Mackay IS, Durham SR. Oxymetazoline nasal spray three times daily for four weeks in normal subjects is not associated with rebound congestion or tachyphylaxis. Rhinology 2003;41:167-74.

10. Yoo JK, Seikaly H, Calhoun KH. Extended use of topical nasal decongestants. Laryngoscope 1997;107:40-3.

11. Akerlund A, Bende M. Sustained usage of xylometasoline nose drops aggravates vasamotor rhinitis. American J of Rhinology 1991;5:157-60.

12. Tas A, Yagiz R, Yalcin O, Uzun C, Huseyinova G, Adali MK, et al. Use of mometasone furoate aqueous nasal spray in the treatment of rhinitis medicamentosa: an experimental study. Otolaryngol Head Neck Surg 2005;132:608-12.

13. Graf PM, Hallen H. Changes in nasal reactivity in patients with rhinitis medicamentosa after treatment with fluticasone proprionate and placebo nasal spray. ORL J Otorhinolaryngol Relat Spect 1998;60:334-8.

14. Passali D, Salerni L, Passali G, Passali F, Bellussi L. Nasal decongestants in the treatment of chronic nasal obstruction: efficacy and safety of use. Expert Opin Drug Saf 2006;5:783-90.

15. Lockey RF. Rhinitis medicamentosa and stuffy nose. J Allergy Clin Immunol 2006;118:1017-8.

16. Noutsios GT, Willis AL, Ledford JG, Chang EH. Novel role of Surfactant Protein A in bacterial sinusitis. Int Forum Allergy Rhinol 2017;7:897-903.

17. Zucker SM, Barton BM, McCoul ED. Management of rhinitis medicamentosa: a systematic review. Otolaryngol Head Neck Surg 2019;160:429-38.

18. Zhu ZH, Shan YJ, Han Y, Zhu LW, Ma ZX. Pathological study of 
otitis media with effusion after treatment with intranasal pulmonary surfactant. Laryngoscope 2013;123:3148-55.

19. Brown LC, Scott MG. Nasal irrigations: good or bad. Curr Opin Otolaryngol Head Neck Surg 2004;12:9-13.

20. Garavello W, Romagnoli M, Sordi L, Gaini MR, Berardina CD, Angrisono A. Hypersaline nasal irrigation in children with symptomatic seasonal allergic rhinitis: a randomised study. Pediatr Allergy Immunol 2003;14:140-3.

21. Rabago D, Pasic T, Zgierska A. The efficacy of hypersaline nasal irrigation for chronic sinonasal symptoms. Otolaryngol Head and Neck Surg 2005;133:3-8.

22. Hallén H, Enerdal J, Graf P. Fluticasone proppionate nasal spray is more effective and has faster onset of action than placebo in treatment of rhinitis medicamentosa. Clinical and Experimental Allergy 1997;27:552-8.

23. Ferguson BJ, Paramaesvaran S, Rubinstein E. A study of the effect of nasal steroid sprays in perennial allergic rhinitis patients with rhinitis medicamentosa. Otolaryngol Head and Neck Surg 2001;125:253-60.

24. Cam B, Sari M, Midi A, Gergin O. Xylitol treats nasal mucosa in rhinitis medicamentosa: an experimental rat model study Eur Arch Otorhinolaryngol 2019;276:3123-30.

25. Fowler J, Chin CJ, Massoud E. Rhinitis medicamentosa: a nationwide survey of Canadian otolaryngologists. J Otolaryngol Head Neck Surg 2019;48:70.

\section{Sürfaktanın Rinitis Medikamentoza Tedavisinde Etkin Rolü Var Mı? Deneysel Hayvan Çalışması}

Amaç: Rinit medikamentoza (RM), çoğunlukla topikal dekonjestanların uzun süreli, aşırı ve yanlış kullanımı ile ilişkili, alerjik olmayan bir rinit şeklidir. Günümüzde bilinen tek etkin tedavi yöntemi nazal steroidlerdir. Çalı̧mamızda, RM’de ortaya çıkan mukozal değişikliklerin sürfaktan tatbiki ile geri dönüşümünü sağlamayı amaçladık. Ayrıca, sürfaktanın etkinliğini karşılaştırmak amacıyla farklı gruplara farklı moleküller de uygulandı.

Gereç ve Yöntem: Otuz sıçan beş gruba ayrıldı. Tüm gruplar 30 gün boyunca \%0.05 topikal oksimetazolin ile tedavi edildi. Silya kaybı, konjesyon, ödem, goblet hücre artışı ve mukus bezlerindeki artış, skuamöz metaplazi ve kronik enflamatuvar hücre infiltrasyonu ana parametreler olarak belirlendi. Beşinci gruptaki sıçanlar RM ile uyumlu mukozal değişikliklerin varlığını kanıtlamak amacıyla sakrifıye edildi. Histopatolojik inceleme döneminde ( 15 gün), kalan gruplara oksimetazolin uygulanmaya devam edildi. Tedavi yöntemleri Grup I'de salin yıkaması (\%0.09 NaCl), Grup 2'de mometazon furoat monohidrat $50 \mu \mathrm{g} \% 0.05$, Grup 3'te sürfaktan yıkama çözeltisi I damla/ 100 cc ve Grup 4 'te mometazon furoat monohidrat ile intranazal sürfaktan birlikte 15 gün boyunca uygulandı. Altmışıncı günün sonunda tüm sıçanlar dekapite edilerek histopatolojik değerlendirme için patolojiye gönderildi.

Bulgular: Salin ve mometazon furoat ile tedavi edilen gruplarda nazal mukozal konjesyonda anlamlı gerileme izlendi $(p=0.005)$. Silya kaybı regresyonu değerlendirilmesinde, gruplar arasında anlamlı bir fark görülmedi; ancak beklenmedik şekilde salin grubunda \%83 oranında gerileme görüldü. Ödemin tedavisi için sürfaktan/mometazon furoat kombinasyon tedavisinin anlamlı derecede etkisiz olduğu bulundu ( $p=0.013)$. Kronik enflamatuvar hücre infiltrasyonu açııından gruplar arasında istatistiksel fark bulunmadı $(p=0.115)$. Tüm tedavi gruplarında rastlantısal olarak skuamöz metaplazi saptandı ancak gruplar arasında istatistiksel olarak anlamlı bir fark izlenmedi $(p=0.076)$.

Sonuç: Sürfaktan veya sürfaktanın nazal steroid ile kombinasyonu, RM tedavisinde anlamlı etkinliğe sahip değildir.

Anahtar Sözcükler: Mometazon furoat; nazal mukoza; rinitis medikamentoza, sürfaktant. 